Prepared in cooperation with the U.S. Environmental Protection AgencyGreat Lakes Restoration Initiative

\title{
Water-Quality Sampling Plan for Evaluating the Distribution of Bigheaded Carps in the Illinois Waterway
}

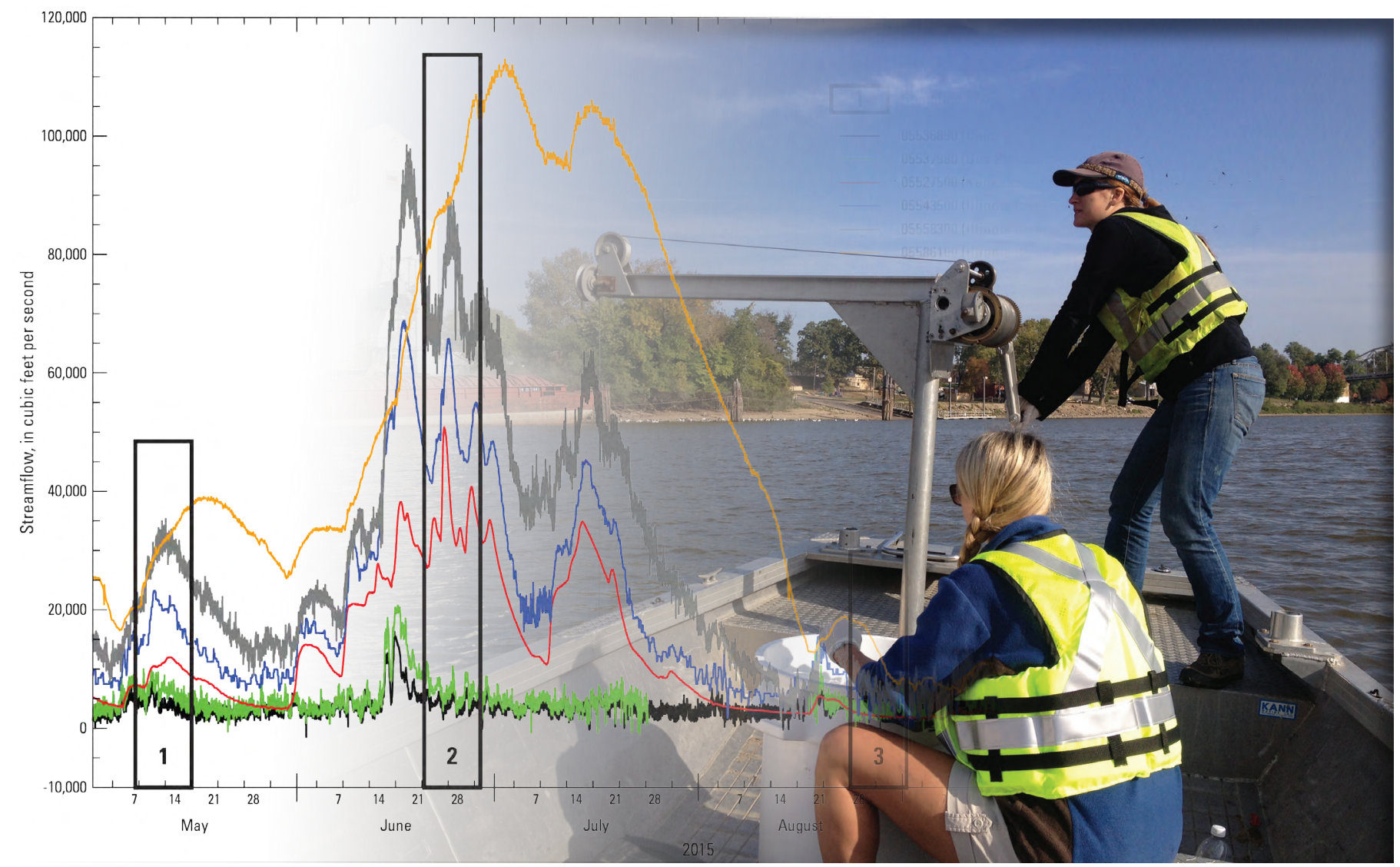

Open-File Report 2017-1019 
Cover image. Combined report figures 3 and 4 ; discharge hydrographs from the six U.S. Geological Survey streamgaging stations (page 6) and U.S. Geological Survey staff collecting water-quality samples in the Illinois Waterway (page 7). Photograph by J. Duncker. 


\section{Water-Quality Sampling Plan for Evaluating the Distribution of Bigheaded Carps in the Illinois Waterway}

By James J. Duncker and Paul J. Terrio

Prepared in cooperation with the U.S. Environmental Protection Agency-

Great Lakes Restoration Initiative

Open-File Report 2017-1019 


\title{
U.S. Geological Survey William H. Werkheiser, Acting Director
}

\author{
U.S. Geological Survey, Reston, Virginia: 2017
}

For more information on the USGS - the Federal source for science about the Earth, its natural and living resources, natural hazards, and the environment—visit http://www.usgs.gov or call 1-888-ASK-USGS.

For an overview of USGS information products, including maps, imagery, and publications, visit http://www.usgs.gov/pubprod/.

Any use of trade, firm, or product names is for descriptive purposes only and does not imply endorsement by the U.S. Government.

Although this information product, for the most part, is in the public domain, it also may contain copyrighted materials as noted in the text. Permission to reproduce copyrighted items must be secured from the copyright owner.

Suggested citation:

Duncker, J.J., and Terrio, P.J., 2017, Water-quality sampling plan for evaluating the distribution of bigheaded carps in the Illinois Waterway: U.S. Geological Survey Open-File Report 2017-1019, 9 p., https://doi.org/10.3133/ofr20171019.

ISSN 2331-1258 (online) 


\section{Contents}

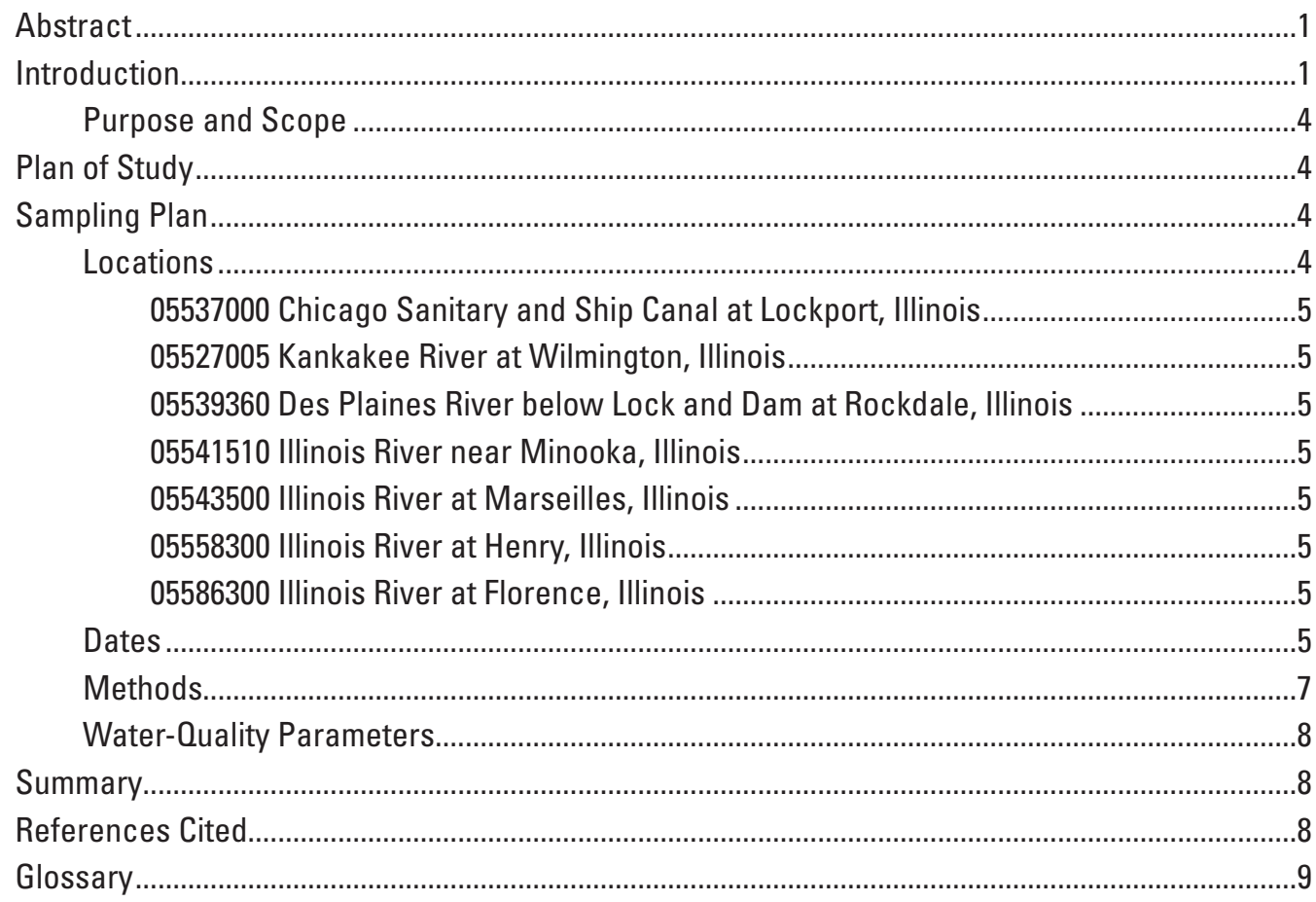

\section{Figures}

1. Study area map of the Illinois Waterway showing sampling locations, lock and dams, and U.S. Geological Survey streamflow-gaging stations

2. Map showing the presence of bighead and silver carp in the Illinois Waterway (map courtesy of the U.S. Fish and Wild life Service, 2016) .............................................

3. Discharge hydrographs from the six U.S. Geological Survey streamgaging stations used during the study with the four sampling periods identified...

4. Photograph of U.S. Geological Survey staff collecting water-quality samples in the Illinois Waterway near Henry, Illinois, during the fourth sampling round on October 8, 2015

\section{Tables}

1. U.S. Geological Survey gaging station number, name, latitude, longitude, and river mile for sampling locations in this study.

2. Laboratory schedules, descriptions, and associated laboratory for water-quality sample analyses used in this study 


\section{Conversion Factors}

U.S. customary units to International System of Units

\begin{tabular}{lcl}
\hline & Multiply & \multicolumn{1}{c}{ To obtain } \\
\hline inch (in.) & Length & \\
inch (in.) & 2.54 & centimeter $(\mathrm{cm})$ \\
inch (in.) & 25.4 & millimeter $(\mathrm{mm})$ \\
foot (ft) & 25,400 & micrometer $(\mu \mathrm{m})$ \\
mile (mi) & 0.3048 & meter $(\mathrm{m})$ \\
\hline & 1.609 & kilometer $(\mathrm{km})$ \\
\hline ounce, fluid (fl. oz) & Volume & \\
pint (pt) & 0.02957 & liter $(\mathrm{L})$ \\
quart (qt) & 0.4732 & liter $(\mathrm{L})$ \\
gallon (gal) & 0.9464 & liter $(\mathrm{L})$ \\
\hline & 3.785 & liter $(\mathrm{L})$ \\
\hline foot per second (ft/s) & Flow rate & \\
cubic foot per second (ft $/ \mathrm{s})$ & 0.3048 & meter per second $(\mathrm{m} / \mathrm{s})$ \\
million gallons per day $(\mathrm{Mgal} / \mathrm{d})$ & 0.02832 & cubic meter per second $\left(\mathrm{m}^{3} / \mathrm{s}\right)$ \\
\hline
\end{tabular}

Temperature in degrees Fahrenheit $\left({ }^{\circ} \mathrm{F}\right)$ may be converted to degrees Celsius $\left({ }^{\circ} \mathrm{C}\right)$ as follows:

$$
{ }^{\circ} \mathrm{C}=\left({ }^{\circ} \mathrm{F}-32\right) / 1.8 \text {. }
$$

\section{Datum}

Vertical coordinate information is referenced to the North American Vertical Datum of 1927 (NAVD 27).

Horizontal coordinate information is referenced to the North American Datum of 1983 (NAD 83).

\section{Supplemental Information}

Words shown in bold are defined in the glossary.

\section{Abbreviations}

IWW Illinois Waterway

USACE U.S. Army Corps of Engineers

USGS U.S. Geological Survey 


\title{
Water-Quality Sampling Plan for Evaluating the Distribution of Bigheaded Carps in the Illinois Waterway
}

\author{
By James J. Duncker and Paul J. Terrio
}

\section{Abstract}

The two nonnative invasive bigheaded carp species (bighead carp Hypophthalmichthys nobilis and silver carp $H$. molitrix) that were accidentally released in the 1970s have spread widely into the rivers and waterways of the Mississippi River Basin. First detected in the lower reaches of the Illinois Waterway (IWW, the combined Illinois River-Des Plaines River-Chicago Area Waterway System) in the 1990s, bighead and silver carps moved quickly upstream, approaching the Chicago Area Waterway System. The potential of substantial negative ecological and economic impact to the Great Lakes from the presence of these species is a concern. However, since 2006, the population front of bigheaded carps has remained in the vicinity of Joliet, Illinois, near river mile 278. This reach of the IWW is characterized by stark changes in habitat, water quality, and food resources as the waterway transitions from a primarily agricultural landscape to a metropolitan and industrial canal system. This report describes a 2015 plan for sampling the IWW to establish water-quality conditions that might be contributing to the apparent stalling of the population front of bigheaded carps in this reach. A detailed description of the study plan, Lagrangian-style sampling approach, selected analytes, sampling methods and protocols are provided. Hydrographs from streamflow-gaging stations show IWW conditions during the 2015 sampling runs.

\section{Introduction}

Bigheaded carps (bighead and silver carps) were first introduced into U.S. waters in the 1970s and since have spread widely within the Mississippi River Basin (Kolar and others, 2007; Chapman and Hoff, 2011). These two species of bigheaded carps have been present in the Illinois Waterway (IWW) since the 1990s (Irons and others, 2011) (fig. 1). The potential of substantial negative ecological and economic impact to the Great Lakes from the presence of these species (Mandrake and Cudmore, 2004; Kolar and others, 2007) is a concern. However, since 2006, the population front has remained in the vicinity of Joliet, Illinois, near river mile 278 (fig. 2). This reach is characterized by several significant changes in the waterway in terms of water quality, habitat, and available food resources. Water quality significantly changes above the confluence of the Kankakee River and Des Plaines River. Above this confluence, the Des Plaines River is comprised of primarily treated wastewater effluent and urban/suburban runoff. Above the confluence of the Kankakee River and Des Plaines River, the habitat quickly changes from a riverine setting to a more industrial canal. Farther upstream on the lower Des Plaines River, the available food resources for bigheaded carps diminish as water-quality sampling has indicated lower algal concentrations and fewer productive backwater settings. The hypothesis for this study is that some factor or a combination of factors is contributing to the apparent stalling of the bigheaded carp population front in this reach of the waterway. In order to test this hypothesis, a plan of study was developed to evaluate the potential impact that the changing water-quality conditions within the IWW might have on the movement and distribution of bigheaded carps.

Recent studies have indicated that a broad range of chemicals used in homes, industry, and agriculture enter the environment through wastewater effluent (Barber and others, 2000; Barnes and others, 2002; Kolpin and others, 2002: Vajda and others, 2011). These chemicals include, but are not limited to, pharmaceuticals, hormones, detergents, disinfectants, fire retardants, insecticides, and antioxidants. The U.S. Geological Survey (USGS) National Water-Quality Assessment Program summary of intensive water-quality sampling of the upper Illinois River Basin from 1975 to 1990 identified the presence of herbicides, pesticides, and other synthetic organic compounds in fish tissue (Sullivan and others, 1998). Numerous exceedances of National Academy of Sciences standards for protection of predators on fish were observed in the upper IWW (Sullivan and others, 1998).

The effect of these chemicals on fish is complex and not well understood. The reach of the waterway where the population front has stalled is in the lower Des Plaines River, which contains substantial amounts of wastewater effluent from the Chicago metropolitan area. Wastewater effluents from large urban areas can contain a complex mixture of pharmaceuticals and organic contaminants that may impact reproduction and the overall composition fish communities in rivers (Barber and others, 2006). In the Illinois River, combinations of water quality and habitat have been determined to affect the structure 


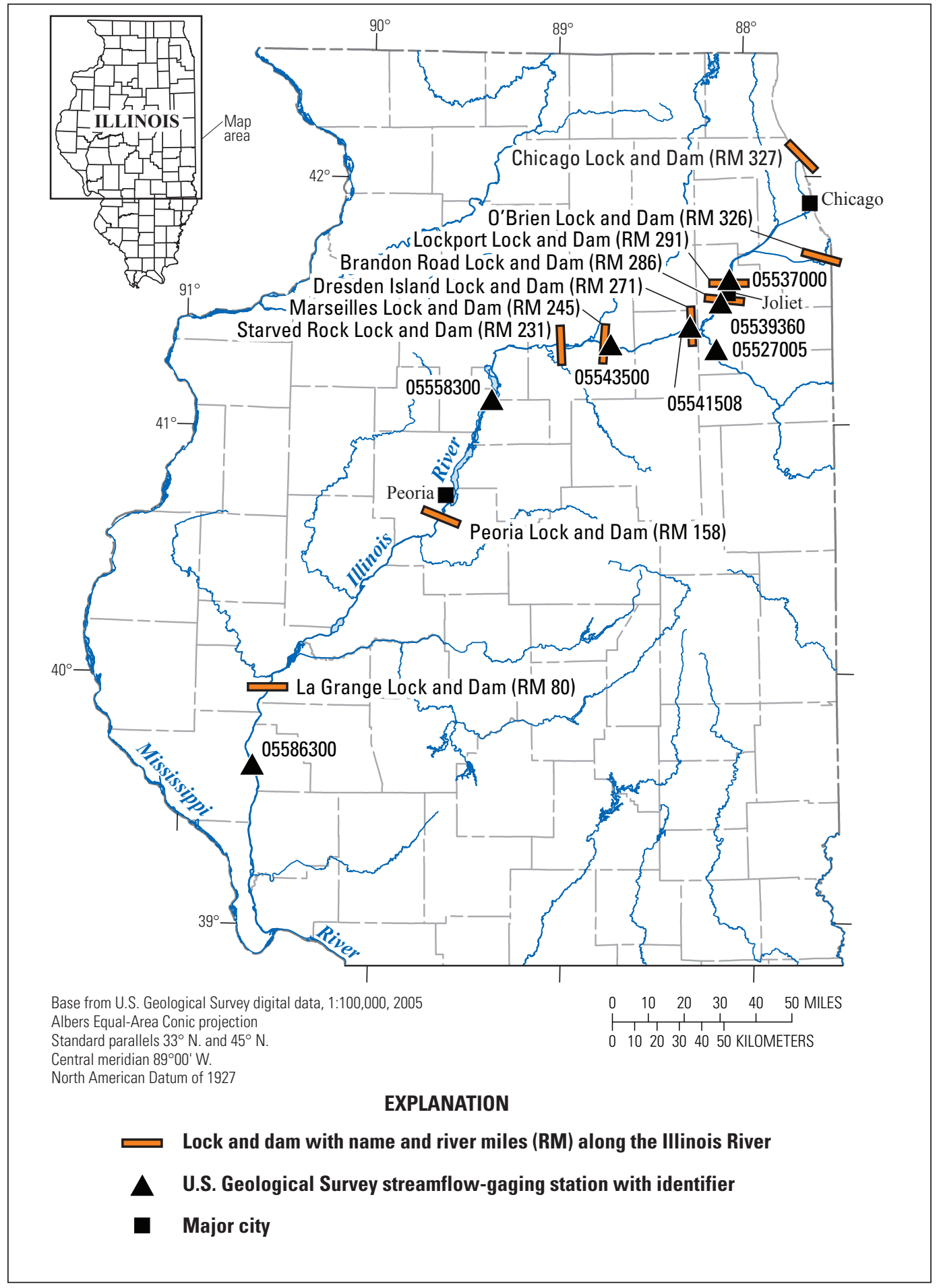

Figure 1. Study area map of the Illinois Waterway showing sampling locations, lock and dams, and U.S. Geological Survey streamflow-gaging stations. 


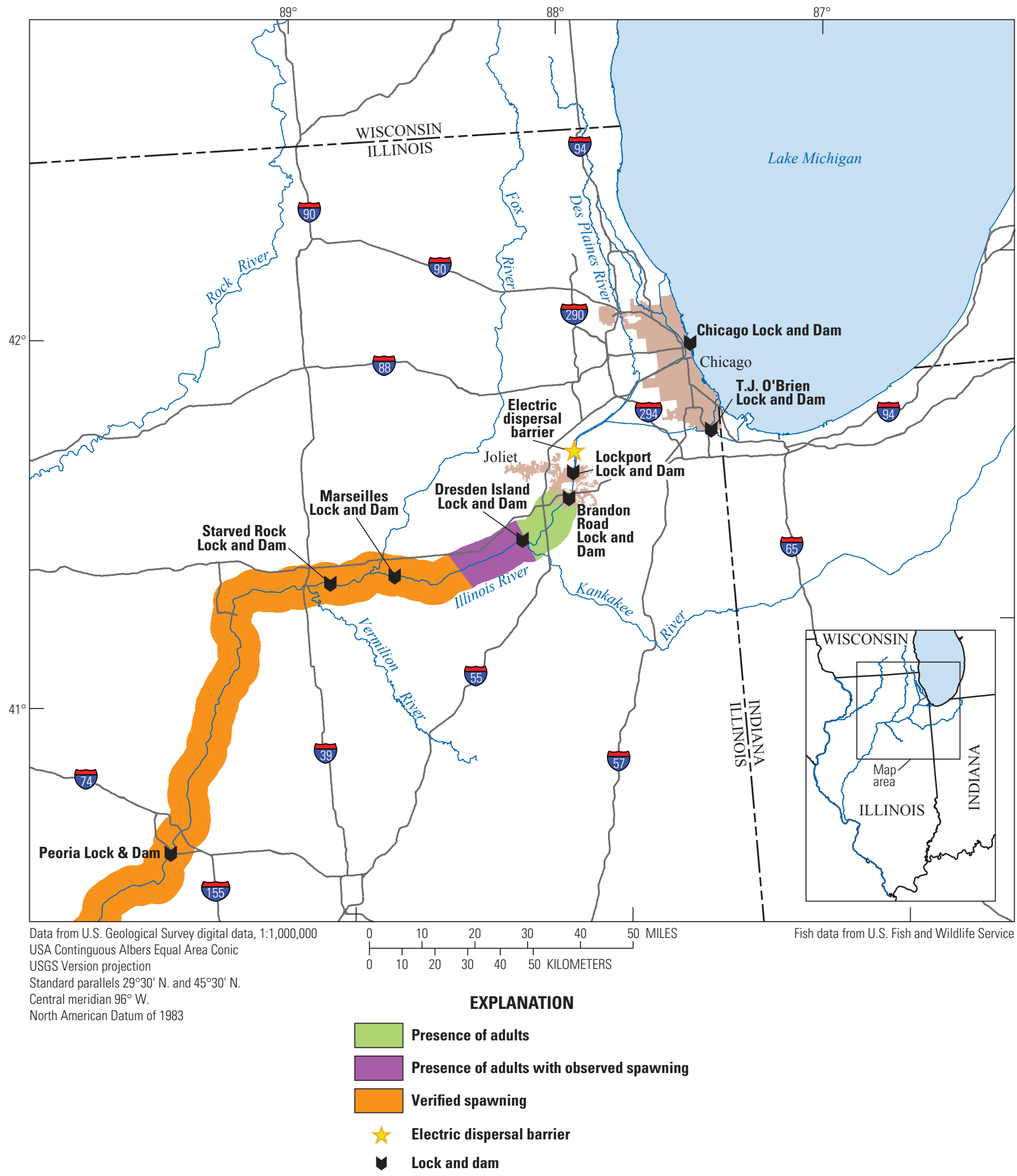

Figure 2. Map showing the presence of bighead and silver carp in the Illinois Waterway (map courtesy of the U.S. Fish and Wildlife Service, 2016). 
of fish communities (Pegg and McClelland, 2004). The arrival of invasive bigheaded carps also changed the structure of fish communities in the Illinois River (Irons and others, 2007; Pendleton and others, 2014). The data collected in this study will define baseline (2015) water-quality conditions that might impact the movement and distribution of bigheaded carps in the Illinois Waterway.

\section{Purpose and Scope}

The purpose of this report is to describe the study plan for a Lagrangian-style sampling of the IWW for pharmaceuticals and other organic wastewater contaminants that might impact the movement and distribution of bigheaded carps. The report was prepared in cooperation with the U.S. Environmental Protection Agency's Great Lakes Restoration Initiative.

The scope of this report is a description of the study plan that addresses sample site selection, sample collection date and times, flow conditions during sampling, sampled constituents, and the methods used to collect the water-quality samples.

\section{Plan of Study}

The Illinois Department of Natural Resources, U.S. Fish and Wildlife Service, U.S. Army Corps of Engineers (USACE), and others conduct routine, systematic sampling of bigheaded carps in the IWW. This plan of study outlines the data collection required to characterize the current water-quality conditions during a range of seasonal flow conditions in the IWW. The water-quality data will be analyzed to evaluate the potential role of water quality on the apparent stalling of bigheaded carps in this reach and to test the hypothesis that water quality might impact the distribution and movement of bigheaded carps in the IWW.

The sampling plan generally follows a Lagrangian-style sampling approach. Lagrangian-style sampling attempts to sample the same volume of water as it flows downstream, providing an indication of how the water quality of a volume of water changes as it travels downstream. Mean channel velocities were determined for a range of streamflow conditions from historical USGS discharge measurements at USGS gaging stations. The mean channel velocities were then used to estimate travel time between sampling locations. Changing streamflow conditions, water-level regulation at each of the eight lock and dams along the waterway, and logistical resources, make strict adherence to the Lagrangian-style sampling approach challenging.

\section{Sampling Plan}

This sampling plan will establish a baseline of waterquality data in the IWW at various times during the year and under a range of flow conditions. This information will be used to understand the distribution and movement of bigheaded carps in the IWW. The sampling plan addresses the spatial and temporal variability within the IWW.

\section{Locations}

The IWW is managed by the USACE and other agencies to provide for navigation, flood risk management, construction regulation, recreation, water supply, hydropower and environmental protection and restoration. The eight lock and dams, operated by the USACE, section the waterway into a series of eight associated pools (fig. 1). Water chemistry samples were collected at seven sites (table 1). The sites were selected to represent water-quality conditions along the length of the IWW, considering significant point source inputs (such as major municipal wastewater-treatment plant effluent discharges), and major tributary confluences. Also, if possible, the sites were co-located at USGS streamflow-gaging stations and have readily available discharge information for the date and time of sample collection. Each site was sampled four times during the 2015 study period.

Table 1. U.S. Geological Survey gaging station number, name, latitude, longitude, and river mile for sampling locations in this study.

[CSSC, Chicago Sanitary and Ship Canal; Ill., Illinois, ${ }^{\circ}$, degree; ', minute, “, second; N, north; W, west]

\begin{tabular}{clrrr}
\hline Station number & \multicolumn{1}{c}{ Station name } & Latitude & \multicolumn{1}{c}{ Longitude } & River mile \\
\hline 05537000 & CSSC at Lockport, Ill. & $41^{\circ} 34^{\prime} 14^{\prime \prime} \mathrm{N}$ & $88^{\circ} 04^{\prime} 42^{\prime \prime} \mathrm{W}$ & 291.1 \\
05527005 & Kankakee River at Wilmington, Ill. & $41^{\circ} 18^{\prime} 20^{\prime \prime} \mathrm{N}$ & $88^{\circ} 09^{\prime} 05^{\prime \prime} \mathrm{W}$ & ${ }^{\prime} 9.9$ \\
05539360 & Des Plaines River below Lock and Dam at Rockdale, Ill. & $41^{\circ} 30^{\prime} 09^{\prime \prime} \mathrm{N}$ & $88^{\circ} 06^{\prime} 16^{\prime \prime} \mathrm{W}$ & 285.9 \\
05541510 & Illinois River near Minooka, Ill. & $41^{\circ} 23^{\prime} 36^{\prime \prime} \mathrm{N}$ & $88^{\circ} 18^{\prime} 17^{\prime \prime} \mathrm{W}$ & 270.0 \\
05543500 & Illinois River at Marseilles, Ill. & $41^{\circ} 20^{\prime} 13^{\prime \prime} \mathrm{N}$ & $88^{\circ} 47^{\prime} 04^{\prime} \mathrm{W}$ & 243.0 \\
05558300 & Illinois River at Henry, Ill. & $41^{\circ} 06^{\prime} 21^{\prime \prime} \mathrm{N}$ & $89^{\circ} 21^{\prime} 23^{\prime} \mathrm{W}$ & 195.6 \\
05586300 & Illinois River at Florence, Ill. & $39^{\circ} 37^{\prime} 55^{\prime \prime} \mathrm{N}$ & $90^{\circ} 36^{\prime} 27^{\prime \prime} \mathrm{W}$ & 55.9 \\
\hline
\end{tabular}

${ }^{1}$ River miles above the mouth of the Kankakee River. 


\section{Chicago Sanitary and Ship Canal at Lockport, Illinois}

This sampling location (river mile 291.1) was selected because it is representative of water quality of flow coming out of the Chicago Area Waterway System. This location has a long history of sampling, and samples collected during this study could be compared to historical data collected at this location by USGS and other agencies. Discharge data are recorded at the USGS gaging station number 05536890 Chicago Sanitary and Ship Canal near Lemont, Ill., which is approximately 11 miles upstream from the sample site. No substantial inflows are between the sampling site and the upstream gaging station.

\section{Kankakee River at Wilmington, Illinois}

This sampling location (9.9 river miles above the mouth of the Kankakee River) was selected because it is representative of water quality and flow coming out of the Kankakee River Basin. The samples at this location were collected from the bridge in Wilmington, Ill. Discharge data for the sampling dates are recorded at the USGS gaging station number 05527500 Kankakee River near Wilmington, Ill., which is approximately 4.3 miles downstream from the sample site. No substantial inflows are between the sample site and the downstream gaging station.

\section{Des Plaines River below Lock and Dam at Rockdale, Illinois}

This sampling location (river mile 285.9) was selected because it is representative of water quality in the Dresden Pool, close to the location of the population front of adult bigheaded carps. Discharge data for the sample dates are recorded at the USGS gaging station number 05537980 Des Plaines River at Route 53 at Joliet, Ill., which is approximately 3.0 miles upstream. No substantial inflows are between the sample site and the upstream gaging station.

\section{Illinois River near Minooka, Illinois}

This sampling location (river mile 270.0) was selected because it is representative of the Marseilles Pool of the Illinois River, is downstream from the confluence with the Kankakee River, and defines downriver gradational changes in water-quality conditions. As of 2015, this reach represented the furthest documented upstream spawning of bigheaded carps in the Illinois River. Discharge data for this sample site are from moving-boat discharge measurements made by USGS staff using an acoustic Doppler current profiler prior to the sample collection.

\section{Illinois River at Marseilles, Illinois}

This sampling location (river mile 243.0) was selected because it is in the Starved Rock Pool of the Illinois River and further defines the downriver gradational changes in water quality. The sampling site is approximately 2 miles downstream from the Marseilles Lock and 4.5 miles downstream from the Marseilles Dam. Discharge data for the sampling dates are recorded at the USGS gaging station number 05543500 Illinois River at Marseilles, Ill., which is approximately 3.5 miles upstream from the sampling site. No substantial inflows are between the Marseilles gaging station and the sample location.

\section{Illinois River at Henry, Illinois}

This sampling location (river mile 195.6) was selected because it is in the Peoria Pool of the Illinois River and should further define the downriver gradational changes in water quality before major input of Peoria wastewater effluent. The upper reaches of the Peoria Pool are representative of waterquality conditions and habitat where juvenile bigheaded carps are routinely sampled by biologists. Discharge data for the sampling dates are recorded at the USGS gaging station number 05558300 Illinois River at Henry, Ill. The sample location is approximately 300 feet downstream from the gaging station.

\section{Illinois River at Florence, Illinois}

This sampling location (river mile 55.9) is below the LaGrange Lock and Dam (in the Alton Pool of the Mississippi River) and is representative of water-quality conditions in the lower reach of the Illinois River. Biologists have routinely documented all life stages of bigheaded carps in the lower reaches of the Illinois River. Discharge data for the sampling dates are recorded at the USGS gaging station number 05586100 Illinois River at Valley City, Ill., which is approximately 4.2 miles upstream from the sampling site. No substantial inflows are between the Valley City gaging station and this sample location.

\section{Dates}

Sample dates were selected to be representative of typical seasonal conditions and variable hydrologic conditions in the IWW (fig. 3). In early 2015, four sampling periods were identified in project planning. Each round of sampling would take the field crew 7-8 days to complete. The dates were selected to accommodate flexibility for changing river conditions. This first sampling round was from May 6 to 14, 2015, and included typical spring medium- to high-flow conditions. The second sampling round was from June 22 to 29, 2015, during high-flow conditions and a major bigheaded carps spawning event. The third sampling round was from August 24 to September 1, 2015, under typical late summer low-flow conditions. The fourth and final sampling round was from October 5 to 13, 2015, during fall low-flow conditions. 


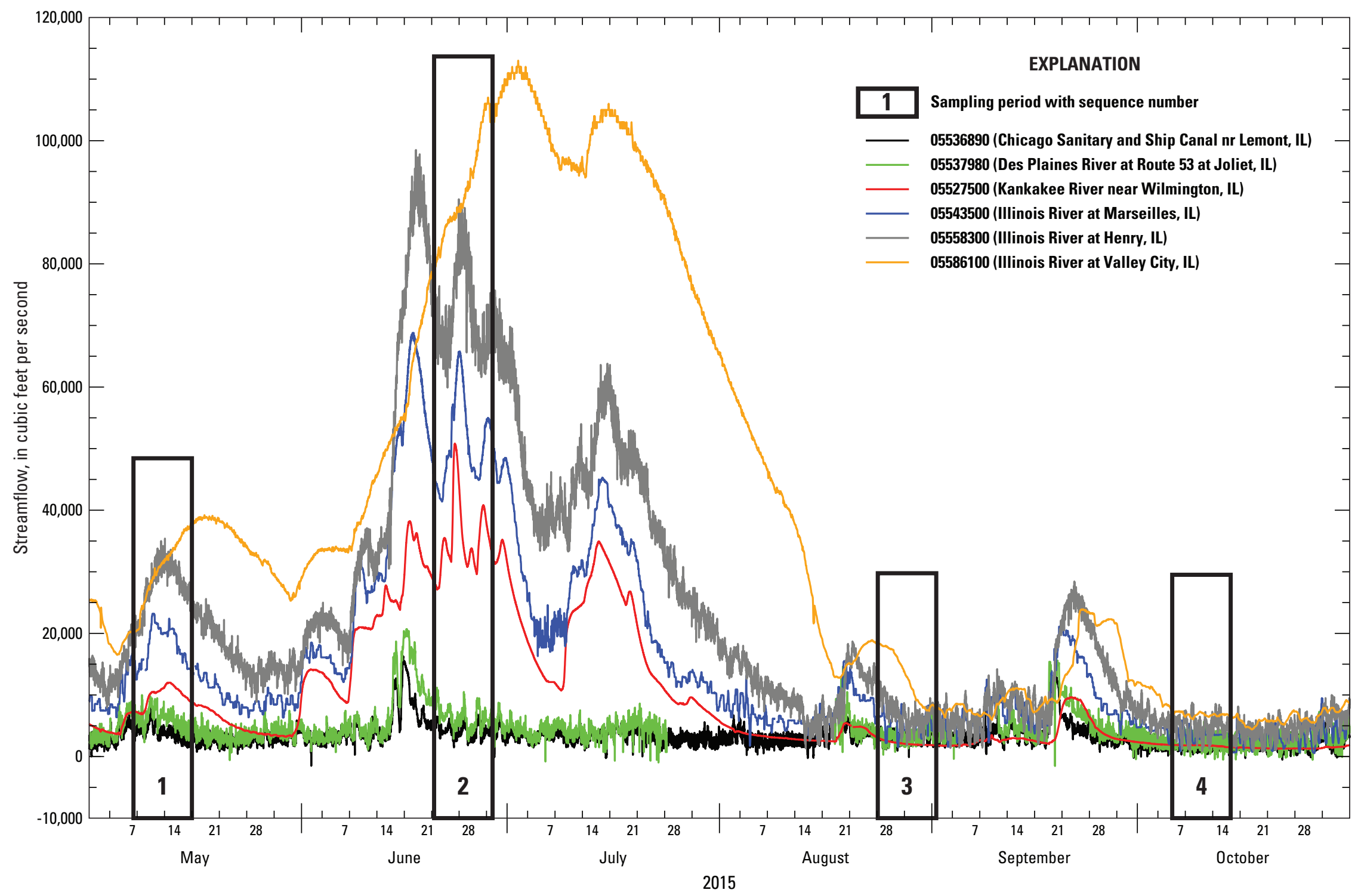

Figure 3. Discharge hydrographs from the six U.S. Geological Survey streamgaging stations used during the study with the four sampling periods identified. 


\section{Methods}

Water-quality samples were collected by USGS staff from the Illinois and Iowa Water Science Centers using nationally consistent, depth- and width-integrating protocols and using sample-processing procedures designed to obtain a representative sample of the water body (U.S. Geological Survey, variously dated). Samples were obtained from either a bridge or boat, as determined by flow conditions and access to the sampling locations. Samples for the three most upstream locations (station number 05537000 Chicago Sanitary and Ship Canal at Lockport, Ill.; station number 05527005 Kankakee River at Wilmington, Ill.; and station number 05539360 Des Plaines River below Lock and Dam at Rockdale, Ill.) were collected from bridges. Samples for the four downstream locations (station number 05541510 Illinois River near Minooka, Ill.; station number 05543500 Illinois River at
Marseilles, Ill.; station number 05558300 Illinois River at Henry, Ill.; and station number 05586300 Illinois River at Florence, Ill.) were collected from a small boat (fig. 4).

Samples were collected using a D-95 or open-bottle sampler, dependent upon stream depth and velocity characteristics (U.S. Geological Survey, 2006). Water samples from individual vertical locations were composited in a 60 -liter Teflon churn and subsequently processed for whole-water or dissolved-chemical constituents. Dissolved-constituent samples were separated using a Pall GWV Versapor capsule filter with a 0.45 -micrometer acrylic copolymer filter. All samples were preserved according to the USGS National Field Manual and National Water Quality Laboratory protocols and methods (Wilde and others, 2004).

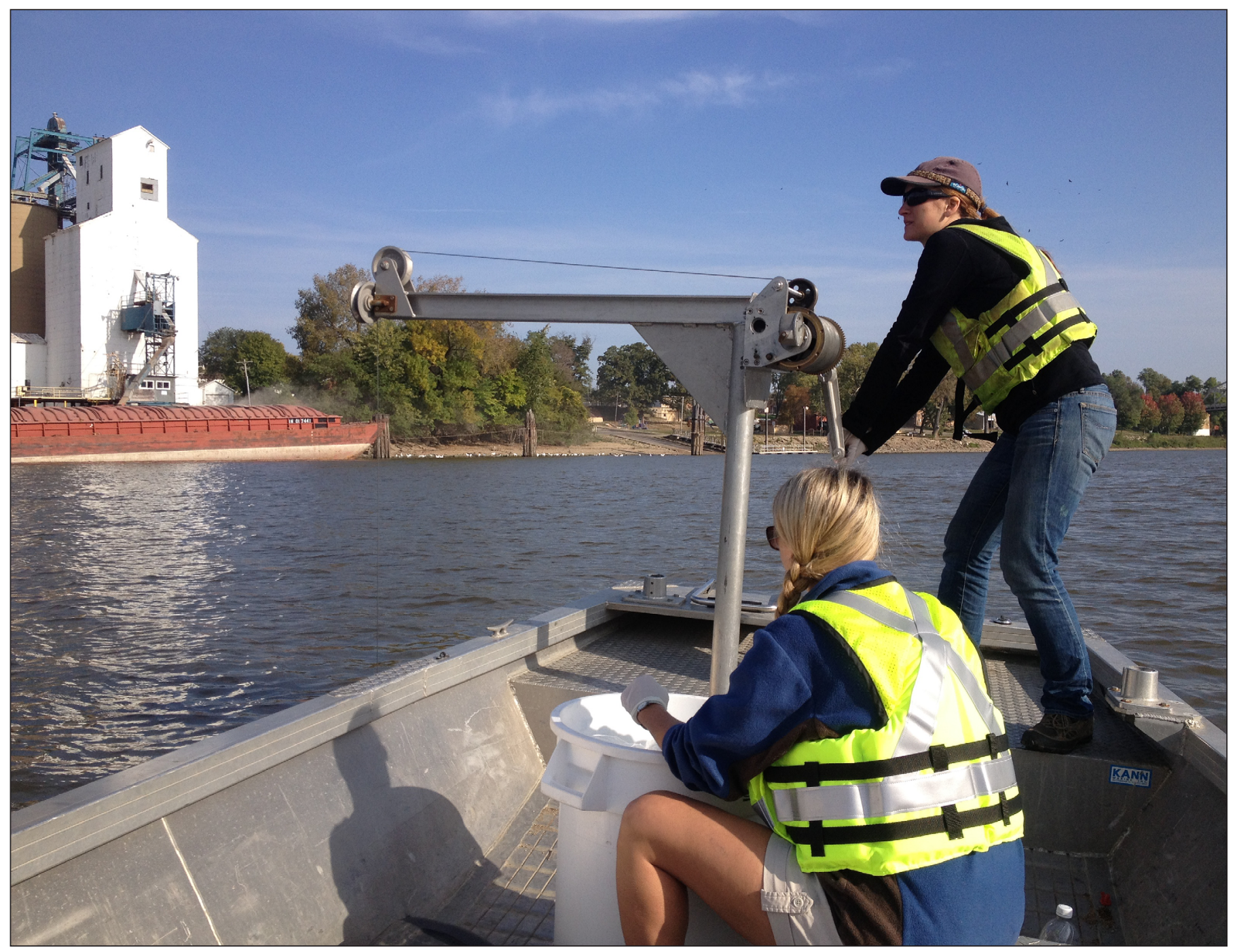

Figure 4. U.S. Geological Survey staff collecting water-quality samples in the Illinois Waterway near Henry, Illinois, during the fourth sampling round on October 8, 2015. (Photograph by J. Duncker) 
Following collection, filtration, and preservation, samples were immediately chilled and sent to the various laboratories as soon as practicable. Samples were sent to the following laboratories for analyses: USGS National Water Quality Laboratory, USGS Kansas Organic Geochemistry Research laboratory, USGS California Water Science Center laboratory, USGS National Research Program Laboratory, Boulder, Colorado (table 2).

Table 2. Laboratory schedules, descriptions, and associated laboratory for water-quality sample analyses used in this study.

[NWQL, U.S. Geological Survey (USGS) National Water Quality Laboratory; KSOGRL, USGS Kansas Organic Geochemistry Research Laboratory; CAWSC, USGS California Water Science Center laboratory; NRPCO, USGS National Research Program laboratory, Boulder, Colorado]

\begin{tabular}{lll}
\hline $\begin{array}{c}\text { Laboratory } \\
\text { schedule }\end{array}$ & \multicolumn{1}{c}{ Description } & Laboratory \\
\hline Schedule 1854 & Trace elements & NWQL \\
Lab code 3211 & Total organic carbon & NWQL \\
Schedule 2437 & Pesticides & NWQL \\
Schedule 2440 & Pharmaceuticals & NWQL \\
Schedule 2524 & Trace elements and major ions & NWQL \\
Schedule 4433 & Wastewater indicators & NWQL \\
Schedule 4434 & Hormones & NWQL \\
Schedule 4437 & Volatile organic compounds & NWQL \\
Schedule 2702 & Nutrients & NWQL \\
Schedule 4440 & Ambient purgeables & NWQL \\
Lab code 8099 & Halogenated organic compounds & NWQL \\
LCGY & Glyphosate and degradates & KSOGRL \\
PFRG-DBP & Disinfection byproducts & CAWSC \\
PFRG-LC & Pesticides & CAWSC \\
Surfactants & Surfactants & NRPCO \\
\hline
\end{tabular}

\section{Water-Quality Parameters}

Field measurements of water-quality properties were made concurrent with the collection of water quality samples at each site during each of the four rounds of sampling. A multi-parameter water-quality meter was used to make field measurements of water temperature, conductivity, $\mathrm{pH}$, and dissolved oxygen following established USGS guidelines (Wilde, ed., variously dated).

Schedules of 15 laboratory analytical schedules were selected to represent the variety of water-quality constituents considered in the project hypothesis as potentially impacting the distribution and movement of bigheaded carps in the IWW. These schedules include the following constituent groups: trace elements, total organic carbon, pesticides, pharmaceuticals, trace metals and major ions, wastewater indicators, hormones, volatile organic compounds, nutrients, ambient purgeables, halogenated organic compounds, glyphosate and glyphosate degradates, disinfection byproducts, and surfactants. Samples were analyzed at four USGS production and research laboratories.

\section{Summary}

During 2015, four rounds of water-quality samples were collected using an approximate Lagrangian-style sampling approach to characterize typical ranges of seasonal flow and water-quality conditions. Water-quality samples were collected by U.S. Geological Survey staff from the Illinois and Iowa Water Science Centers following established U.S. Geological Survey sampling protocols. Schedules of 15 laboratory analyses were selected to represent the variety of water-quality constituents considered in the project hypothesis as potentially impacting the distribution and movement of bigheaded carps in the Illinois Waterway.

\section{References Cited}

Barber, L.B., Brown, G.K., and Zaugg, S.D., 2000, Potential endocrine disrupting organic chemicals in treated municipal wastewater and river water, in Keith, L.H., Jones-Lepp, T.L., and Needham, L.L., eds.; Analysis of environmental endocrine disruptors: Washington D.C., American Chemical Society, ACS Symposium Series 747, p. $97-123$.

Barber, L.B., Murphy, S.F., Verplanck, P.L., Sandstrom, M.W., Taylor, H.E., Furlong, E.T., 2006, Chemical loading into surface water along a hydrological, biogeochemical, and land use gradient-A holistic watershed approach: Environmental Science Technology, v. 40, no. 2, p. 475-486.

Barnes, K.K., Kolpin, D.W., Meyer, M.T., Thurman, E.M., Furlong, E.T., Zaugg, S.D., and Barber, L.B., 2002, Water-quality data for pharmaceuticals, hormones, and other organic wastewater contaminants in U.S. streams, 1999-2000: U.S. Geological Survey Open-File Report 02-94.

Chapman, D.C., and Hoff, M.H., 2011, Invasive Asian carps in North America: American Fisheries Society Symposium 74: $1-3,2011$.

Irons, K.S., Sass, G.G, McClelland, M.A., and Stafford, J.D., 2007, Reduced condition factor of two native fish species coincident with invasion of non-native Asian carps in the Illinois River, U.S.A. Is this evidence for competition and reduced fitness?: Journal of Fish Biology 71, p. 258-273.

Irons, K.S., Sass, G.G., McClelland, M.A., and O'Hara, T.M., 2011, American Fisheries Society Symposium 74: 31-50, 2011. 
Kolar, C.S., Chapman, D.C., Courtenay, W.R., Jr., Housel, C.M., Williams, J.D., and Jennings, D.P., 2007, Bigheaded carps - A biological synopsis and environmental risk assessment: Bethesda, Maryland, American Fisheries Society Special Publication 33.

Kolpin, D.W., Furlong, E.T., Meyer, M.T., Thurman, E.M., Zaugg, S.D., Barber, L.B., and Buxton, H.T., 2002, Pharmaceuticals, hormones, and other organic wastewater contaminants in U.S. streams, 1999-2000-A national reconnaissance: Environmental Science and Technology, v. 36 , no. 6 , p. 1202-1211.

Mandrake, N.E., and Cudmore, B., 2004, Risk assessment for Asian carps in Canada: Ottawa, Quebec, Department of Fisheries and Oceans Canada, Canadian Science Advisory Secretariat Research Document 2004/103, 48 p.

Pegg, M.A., and McClelland, M.A., 2004, Spatial and temporal patterns in fish communities along the Illinois River: Ecology of Freshwater Fish, v. 13, no. 2, p. 125-135.

Pendleton, R., Solomom, L.E., and Casper, A.F., 2014, Longterm changes in fish community structure in relation to Asian carp establishment: American Fisheries Society 144th Annual Meeting, Quebec City, Canada. Conference paper.

Sullivan, D.J., Stinson, T.W., Crawford, J.K., and Schmidt, A.R., Colman, J. A., 1998, Surface-water-quality assessment of the upper Illinois River Basin in Illinois, Indiana, and Wisconsin; pesticides and other synthetic organic compounds in water, sediment, and biota, 1975-90: U.S. Geological Survey Water-Resources Investigations report 96-4135.

U.S. Fish and Wildlife Service, 2016. Presence of bighead and silver carp in Illinois Waterway (map). http://www.asiancarp.us/documents/map103015.pdf.

U.S. Geological Survey, variously dated, National field manual for the collection of water-quality data: U.S. Geological Survey Techniques of Water-Resources Investigations, book 9, chaps. A1-A10, accessed November 4, 2016, at http://pubs.water.usgs.gov/twri9A.

U.S. Geological Survey, 2006, Collection of water samples (ver. 2.0, Sept. 2006): U.S. Geological Survey Techniques of Water-Resources Investigations, book 9, chap. A4, September 2006, accessed May 1, 2015, at http://pubs.water.usgs.gov/twri9A4/.

Vajda, A.M., Barber, L.B., Gray, J.L., Lopez, E.M., Bolden, A.M., Schoenfuss, H.L., and Norris, D.O., 2011, Demasculinization of male fish by wastewater treatment plant effluent: Aquatic Toxicology, v. 103, nos. 3-4, p. 213-221.
Wilde, F.D., ed., variously dated, Field measurements: U.S. Geological Survey Techniques of Water-Resources Investigations, book 9, chap. A6, with sec. 6.0-6.8, accessed May 1, 2015, at http://pubs.water.usgs.gov/twri9A6/.

Wilde, F.D., Radtke, D.B., Gibs, Jacob, and Iwatsubo, R.T., eds., 1999 (ver. 2.2, Sept. 2004 with updates through 2009), Processing of water samples: U.S. Geological Survey Techniques of Water-Resources Investigations, book 9, chap. A5, April 2004, accessed May 1, 2015, at http://pubs.water.usgs. gov/twri9A5/.

\section{Glossary}

Bigheaded carp A term describing the genus Hypophthalmicthys, of which two species $H$. nobilis (bighead carp) and H. molitrix (silver carp), have become widely distributed in portions of the Illinois Waterway.

Lagrangian-style sampling A sampling design in which one attempts to follows the same parcel of water as it moves downstream.

\author{
For additional information, contact: \\ Director, Illinois-lowa Water Science Center \\ U.S. Geological Survey \\ 405 North Goodwin AvenueUrbana, \\ Illinois 61801 \\ http://il.water.usgs.gov \\ Prepared by the U.S. Geological Survey, \\ Science Publishing Network, \\ Madison Publishing Service Center
}




